\title{
ANALISIS KUALITAS LAYANAN PENDIDIKAN DENGAN MENGGUNAKAN INTEGRASI METODE SERVQUAL DAN QFD
}

\author{
Deny Wibisono \\ Program Studi Teknik Industri, FTIK, Universitas Indraprasta PGRI \\ Jl. Nangka No. 58 C Tanjung Barat, Jagakarsa, Jakarta Selatan \\ email: denywibisono80@gmail.com.
}

Diterima: Maret 2018; Disetujui: Maret 2018; dipublikasikan: April 2018

\begin{abstract}
ABSTRAK
Penerapan manajemen mutu pendidikan yang populer dengan istilah Total Quality Education (TQE) menekankan pada pencarian secara konsisten terhadap perbaikan yang berkelanjutan untuk mencapai kebutuhan dan kepuasan pelanggan. Penelitian ini bertujuan untuk membantu pihak manajemen sekolah dalam melakukan evaluasi kualitas pelayanan, mengarahkan upaya-upaya perbaikan dengan meningkatkan atribut pelayanan yang lemah. Penelitian dilakukan di SMA YASPORBI dengan mengintegrasikan dua metode yang berbeda, yaitu Servqualdan QFD. Servqual mengidentifikasi kekuatan dan kelemahan kualitas pelayanan, QFD menerjemahkan keinginan pelanggan menjadi respon teknis yang dapat dilakukanoleh pihak manajemen sekolah. Didapatkan sebanyak 11 atribut pelayanan pendidikan yang harus diperbaiki dari 32 atribut pelayanan pendidikan yang ada dengan dua atribut yang menjadi prioritas perbaikan, yaitu guru membantu siswa memilih jurusan perguruan tinggi yang sesuai dengan bakat dan minat siswa dan adanya pelatihan dalam menghadapi seleksi penerimaan mahasiswa baru. Pada House of Quality Level 2 diperoleh 4 teknikal respon yang menjadi prioritas untuk dikembangkan oleh pihak manajemen sekolah untuk memenuhi keinginan dan kebutuhan pelanggan, yaitu mengadakan pelatihan, workshop, dan seminar pendidikan, kerjasama sekolah dengan lembaga psikologi, sistem pembelajaran moving class, dan menyusun buku program kegiatan sekolah selama satu tahun.
\end{abstract}

Kata Kunci:Total Quality Education, Servqual, Kualitas Pelayanan, QFD, House of Quality

\begin{abstract}
The application of quality management education that is popular with the term Total Quality Education (TQE) emphasis on finding that is consistent with the continuous improvement to achieve customer needs and satisfaction. This study aims to assist the school management in evaluating the quality of services, direct remediation efforts to improve service attributes weak. The study was conducted in SMA YASPORBI by integrating two different methods, namely SERVQUAL and QFD. Servqual identify the strengths and weaknesses of the quality of service, QFD translates into a customer's desire to do a technical response by the management of the school. Obtained as many as 11 educational service attributes that should be fixed on the 32 attributes of existing educational services with two attributes is a priority repairs, which teachers help students choose college majors that fit theirtalents and interests of students and their training in dealing with the selection of new admissions. In the House of Quality Level 2 obtained four technical response to the priorities to be developed by the school management to meet the wants and needs of customers, namely training, workshops, and educational seminars, and school linkages with institutes of psychology, learning systems moving class, and compiled a book program of activities for the school year.
\end{abstract}

Keywords: Total Quality Education, Servqual, Service Quality, QFD House of Quality 


\section{PENDAHULUAN}

Salah satu tantangan penting yang dihadapi oleh sekolah, perguruan tinggi maupun universitas adalah bagaimana mengelola sebuah institusi pendidikan yang bermutu, dimana saat ini terdapat upaya dari pengelola institusi pendidikan untuk meningkatkan mutu pendidikan berdasarkan manajemen perusahaan. Penerapan manajemen mutu pendidikan ini lebih populer dengan istilah Total Quality Education (TQE). Dasar dari manajemen ini dikembangkan dari konsep Total Quality Manajemen (TQM), yang mulanya diterapkan pada dunia bisnis kemudian diterapkan pada dunia pendidikan. Secara filosofis, konsep ini menekankan pada pencarian secara konsisten terhadap perbaikan yang berkelanjutan untuk mencapai kebutuhan dan kepuasan pelanggan(Sallis, 2016).

Sallis (2016) mengemukakan bahwa organisasi-organisasi terbaik, baik milik pemerintah maupun swasta, memahami mutu dan mengetahui rahasianya. Menemukan sumber mutu adalah sebuah petualangan yang penting. Pelaku-pelaku dunia pendidikan menyadari keharusan mereka meraih mutu tersebut dan menyampaikannya pada pelajar dan anak didik. Sesungguhnya, ada banyak sumber mutu dalam pendidikan, misalnya sarana gedung yang bagus, guru yang terkemuka, nilai moral yang tinggi, hasil ujian yang memuaskan, spesialisasi atau kejuruan, dorongan orang tua, bisnis dan komunitas lokal, sumber daya yang melimpah, aplikasi teknologi yang mutakhir, kepemimpinan yang baik dan efektif, perhatian terhadap anak didik, kurikulum yang memadai, atau juga kombinasi dari faktor-faktor tersebut.

Memposisikan institusi pendidikan sebagai industri jasa, harus memenuhi standar mutu. Institusi dapat disebut bermutu, dalam konsep Total Quality Management (TQM), harus memenuhi spesifikasi yang telah ditetapkan. Secara operasional, mutu ditentukan oleh dua faktor, yaitu terpenuhinya spesifikasi yang telah ditentukan sebelumnya dan terpenuhinya spesifikasi yang diharapkan menurut tuntutan dan kebutuhan pengguna jasa. Mutu pertama disebut quality in fact (mutu sesungguhnya) dan kedua disebut quality in perception (mutu persepsi). Standar mutu produksi dan pelayanan diukur dengan kriteria sesuai dengan spesifikasi, cocok dengan tujuan pembuatan dan penggunaan, tanpa cacat (zero defect) dan selalu baik sejak awal (right first time and every time). Mutu dalam persepsi diukur dalam persepsi diukur dari kepuasan pelanggan atau pengguna, meningkatnya minat, harapan dan kepuasan pelanggan. Dalam penyelenggaraan-nya, quality in fact merupakan profil lulusan institusi pendidikan yang sesuai dengan kualifikasi tujuan pendidikan, yang berbentuk standar kemampuan dasar berupa kualifikasi akademik minimal yang dikuasai peserta didik. Sedangkan quality in perceptionpendidikan adalah kepuasan pelanggan dan bertambahnya minat pelanggan eksternal terhadap lulusan institusi pendidikan (Sallis, 2016).

Tujuan mutu adalah memenuhi kebutuhan-kebutuhan pelanggan, maka hal penting yang perlu diperjelas adalah kebutuhan dan keinginan siapa yang harus dipenuhi? Ditingkat inilah pentingnya membicarakan gagasan tentang 'pelanggan'. Pelanggan dapat dibedakan menjadi pelanggan dalam (internal customer) dan pelanggan luar (external customer). Dalam dunia pendidikan yang termasuk 'pelanggan utama' adalah siswa yang secara langsung menerima jasa, 'pelanggan kedua' yaitu orang tua, gubernur atau sponsor siswa yang memiliki kepentingan langsung secara individu maupun institusi, dan 'pelanggan ketiga' yaitu pihak yang memiliki peran penting, meskipun tidak langsung seperti pemerintah, dunia industri dan masyarakat secara keseluruhan. Jadi, suatu institusi pendidikan tersebut akan disebut bermutu apabila pelanggan internal dan eksternal telah terjalin kepuasan atas jasa yang diberikan.

Berdasarkan pembahasan tersebut, terdapat suatu instansi pendidikan sekolah menengah atas swasta bernama SMA YASPORBI berada di daerah Pancoran Jakarta Selatan, memiliki fasilitas yang lengkap, bangunan sekolah yang nyaman, lapangan olahraga dan tempat parkir yang luas, lingkungan sekolah yang hijau dan bebas polusi, ruang kelas menggunakan AC, toilet yang bersih dan dikelola secara khusus oleh lembaga outsourching, kantin dan perpustakaan yang baik. Disamping fasilitas yang baik, disamping itu juga didukung oleh tenaga pengajar 
yang bersertifikasi dan staf yang berkualitas dan juga memiliki sistem keamanan yang terjamin sehingga proses pelayanan pendidikan dalam kegiatan belajar mengajar menjadi sangat nyaman dan kondusif.

Namun demikian, dalam kurun waktu 3 (tiga) tahun terakhir SMA YASPORBI mengalami penurunan jumlah penerimaan siswa baru yang tersaji dalam Gambar 1.1. serta jumlah lulusan yang diterima atau lolos seleksi penerimaan mahasiswa baru di perguruan tinggi negeri yang tersaji dalam Gambar 1.2. Mengingat hal ini, maka diperlukan adanya pencarian secara konsisten terhadap perbaikan yang berkelanjutan (continuous improvement) terhadap kualitas layanan pendidikan untuk mencapai kebutuhan dan kepuasan pelanggan, maka harapan dengan adanya perbaikan kepuasan semua stakeholder yang terkait dalam layanan akademik dapat meningkatkan jumlah calon siswa baru dan daya saing lulusan agar mampu diterima di perguruan tinggi negeri pada tahun selanjutnya.

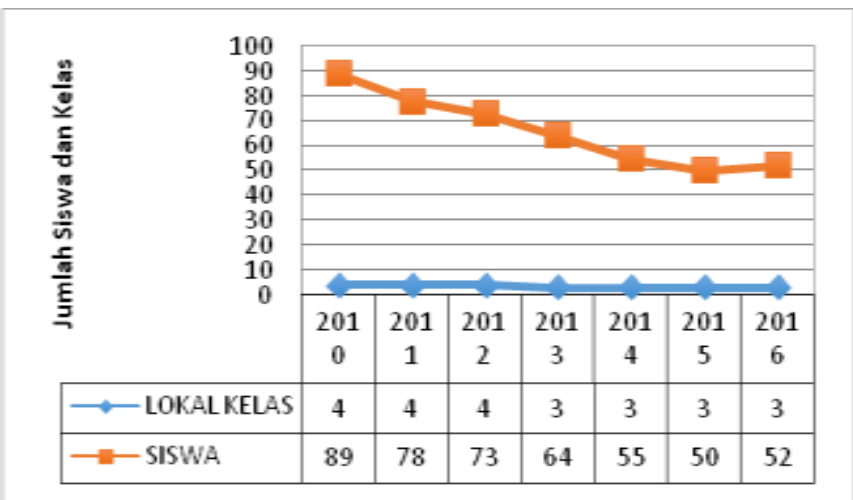

Gambar 1.1.

Grafik Penerimaan Siswa Baru dan Jumlah Lokal KelasPeriode Tahun 2010 s.d. 2016

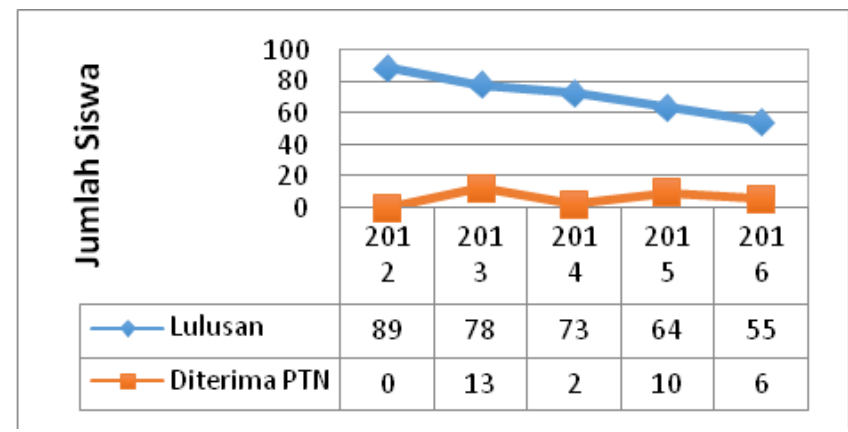

Gambar 1.2.

Grafik Lulusan Lolos Seleksi Masuk Perguruan Tinggi NegeriPeriode Tahun 2012 s.d. 2016

Sesuai pendapat Kitcroen dalam Akhlagi (2012) bahwa jumlah keluhan dikhawatirkan bisa menimbulkan image buruk institusi pendidikan yang berpengaruh pada jumlah siswa baru yang akan mendaftar. Selain itu berpengaruh pada akreditasi sekolah di masa depan. Berikut grafik hasil survey kepuasan layanan akademik SMA YASPORBI Tahun 2014 : 


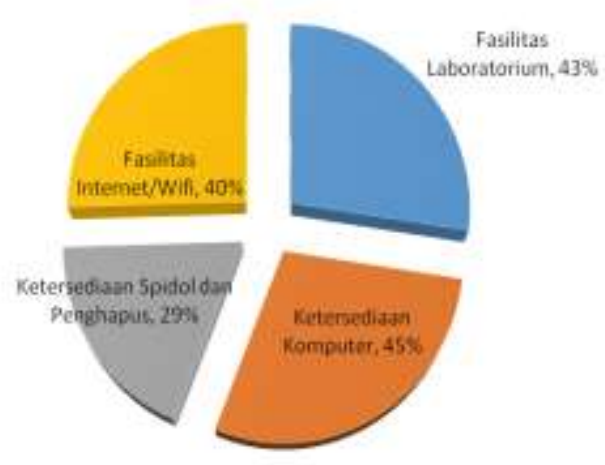

Gambar 1.3.

Grafik Hasil Survei Tingkat Kepuasan Layanan Akademik Tahun 2014 Sumber : Administrasi Tata Usaha SMA YASPORBI, 2016

Oleh karena itu, penelitian yang berkaitan dengan kualitas sistem pelayanan pendidikan yang diberikan kepada siswa yang ada di SMA YASPORBI adalah apakah kualitas sistem pelayanan pendidikan yang ada telah sesuai dengan keinginan dan harapan siswa dan pihak manajemen sekolah. Penelitian ini akan membantu pihak manajemen mengetahui kualitas sistem pelayanan pendidikan selama ini dan memberikan masukan kepada pihak manajemen untuk meningkatkan kualitas sistem pelayanan pendidikan di SMA YASPORBI mereka dengan membuat prioritas peningkatan berdasarkan tingkat kualitas dan atribut-atribut. Dengan mengetahui atribut-atribut pelayanan dengan benar maka perusahaan akan mampu memperbaiki dan meningkatkan kualitas lembaga pendidikannya menjadi efektif dan efisien.

Model Servqual (singkatan dari service quality) yang dikembangkan oleh Parasuraman et. al (1985) adalah merupakan model kualitas jasa yang paling populer dan dijadikan acuan dalam riset manajemen dan pemasaran jasa yang dikenal dengan istilah Gap Analisys Model yang berkaitan erat dengan model kepuasan pelanggan. Model ini menegaskan bila kinerja pada suatu atribut (attribute Performance) meningkat lebih besar daripada harapan (expectations) atas atribut bersangkutan, maka persepsi terhadap kualitas jasa akan menjadi positif dan sebaliknya.

Quality Function Deployment (QFD) berkaitan dengan (1) menetapkan apa yang akan memuaskan pelanggan dan (2) menerjemahkan keinginan pelanggan pada desain yang dijadikan sasaran. Idenya adalah untuk memahami keinginan pelanggan dan memperkenalkan solusi proses alternatif kepada mereka. Kemudian, informasi ini dipadukan diawal proses desain untuk membantu menetapkan apa yang dapat memuaskan pelanggan dan dimana upaya-upaya kualitas perlu disebarkan. Suatu perangkat QFD adalah rumah kualitas (House of Quality), rumah kualitas merupakan teknik grafis untuk menjelaskan hubungan antara keinginan pelanggan dan produk (atau jasa) (Heizer dan Render, 2009).

Penelitian terdahulu oleh Hanggara (2010) menggunakan integrasi Servqual dan QFDpada sekolah SMKN 6 Kota Malang, dimana hasilnya menunjukkan fungsi dari integrasi tersebut adalah memperjelas perencanaan untuk melakukan perbaikan. Integrasi ini dilakukan dengan memanfaatkan gap persepsi dan ekspektasi pada room I House of Quality, dan hasil dari pengukuran Servqual digunakan pada room II House of Quality.

Penelitian lainnya oleh Wulandari (2014) menggunakan integrasi Servqual dan QFD pada Prodi S1 Sistem Informasi STIKOM Surabaya, dimana hasil akhir dari penelitian ini adalah rancangan strategi perbaikan layanan pendidikan program studi S1 Sistem Informasi STIKOM Surabaya, yaitu maintenance komputer, perbaikan komputer yang rusak, pemberian pendidikan dan pelatihan bagi dosen dan karyawan serta penambahan bandwith. 


\section{METODE}

Jenis penelitian yang dilakukan adalah lebih menekankan pada pendekatan kuantitatif. Alasan menggunakan metode ini adalah karena untuk memberikan gambaran mengenai gejala yang dan atau fenomena yang terjadi di SMA YASPORBI yang berkaitan dengan kualitas layanan jasa pendidikan yang ditawarkan oleh SMA YASPORBI dalam upaya meningkatkan pelayanan dilihat dari sisi siswa. Dengan objek penelitian ini siswa SMA YASPORBI Kelas XII atau tingkat akhir pada level pendidikan Sekolah Menengah Atas.

Penelitian ini adalah mengenai kualitas pelayanan yang ada di sekolah YASPORBI sebagai obyek penelitian, tujuan dari penelitian ini yaitu untuk mengetahui atribut-atribut yang dianggap penting oleh konsumen serta tingkat kepentingan siswa terhadap atribut layanan pendidikan obyek penelitian, selain itu juga untuk mengetahui prioritas prosedur kualitas pelayanan yang sesuai dengan keinginan siswa. Seperti pada matrik pengembangan QFD dengan langkah tahapan (1) keinginan konsumen menuju ke parameter teknik (2) parameter teknik menuju ke kebutuhan proses dan (3) kebutuhan proses menuju ke prosedur kualitas.

Kuesioner adalah sebuah kumpulan pertanyaan yang secara logis berhubungan dengan masalah penelitian dan tiap pertanyaan merupakan jawaban-jawaban yang mempunyai makna dalam menguji hipotesa. Kuesioner ini diberikan kepada siswa SMA YASPORBI sebagai obyek penelitian untuk mengetahui atribut-atribut apa yang diinginkan konsumen, sehingga suara konsumen dapat dijadikan data untuk penelitian. Kuesioner ini disebarkan kepada 75 responden yang merupakan sampel sesungguhnya dari obyek penelitian. Kuesioner ini disusun dengan skala Likert dan yang digunakan adalah 1 sampai 5. Kuesioner ini digunakan untuk mencari derajat kepentingan atau harapan dan derajat persepsi atau kenyataan yang didapatkan oleh konsumen berkaitan dengan pelayanan di Sekolah YASPORBI obyek penelitian yang sesuai dengan pendapat konsumen.

Dalam penelitian ini, data-data untuk pengukuran kualitas pelayanan (Servqual) diperoleh dari kuesioner yang disebarkan. Sedangkan data-data yang lain menyangkut : penyusunan respon teknikal, arah pengembangan respon teknikal, korelasi antar respon teknikal, data tingkat kesulitan organisasi dalam karakteristik proses, target, korelasi antara atribut-atribut pelayanan dan respon teknikal dalam penyusunan House of Qualitylevel 1, diperoleh dari wawancara dengan pihak manajemen SMA YASPORBI dan Yayasan YASPORBI, obyek penelitian serta dari dokumen-dokumen organisasi.

Variabel dalam tesis ini terdiri dari variabel kinerja SMA YASPORBI / Persepsi Pengguna $(\mathrm{P})$ dan variabel harapan/ekspektasi kepuasan pengguna (E). Variabel $\mathrm{P}$ berdasarkan atas kinerja SMA YASPORBI untuk melayani penggunanya dalam lima dimensi servqual dimana didalam metode servqual membagi kualitas pelayanan ke dalam lima dimensi yaitu tangibles (bukti langsung/P1), reliability (kehandalan/P2), responsiveness (daya tanggap/P3), assurance (jaminan/P4) dan emphaty (empati/P5). Sedangkan variabel E berdasarkan harapan atau ekspektasi kepuasan pengguna terhadap pelayanan yang diberikan SMA YASPORBI dalam lima dimensi Servqual yaitu tangibles (bukti langsung/E1), reliability (kehandalan/E2), responsiveness (daya tanggap/E3), assurance (jaminan/E4) dan emphaty (empati/E5)

Tabel 1 Variabel Penelitian

\begin{tabular}{lll}
\hline \multicolumn{1}{c}{ Variabel } & \multicolumn{1}{c}{ Dimensi } & \multicolumn{1}{c}{ Indikator } \\
\hline $\begin{array}{l}\text { Layanan Pendidikan } \\
\text { (Goetsch \& Davis, 2010) }\end{array}$ & Reliability & $\begin{array}{l}\text { Prosedur layanan penerimaan siswa mudah } \\
\text { dan cepat }\end{array}$ \\
\hline & & $\begin{array}{l}\text { Proses belajar mengajar dijalankan dengan } \\
\text { baik dan lancar }\end{array}$ \\
\hline & $\begin{array}{l}\text { Jadwal pelajaran dijalankan dengan tepat } \\
\text { dan disiplin }\end{array}$ \\
\hline
\end{tabular}




\begin{tabular}{|c|c|c|}
\hline Variabel & Dimensi & Indikator \\
\hline & & $\begin{array}{lccr}\text { Isi pembelajaran } & \text { berguna } & \text { untuk } \\
\text { menyiapkan siswa } & \text { dalam } & \text { seleksi } \\
\text { penerimaan mahasiswa baru } & \end{array}$ \\
\hline & & $\begin{array}{l}\text { Guru mampu menyampaikan materi } \\
\text { pelajaran dengan baik }\end{array}$ \\
\hline & & $\begin{array}{l}\text { Guru mata pelajaran mengajar sesuai } \\
\text { dengan latar belakang pendidikannya }\end{array}$ \\
\hline & & $\begin{array}{l}\text { Ada pelatihan dalam mempersiapkan siswa } \\
\text { menghadapi seleksi penerimaan mahasiswa } \\
\text { baru }\end{array}$ \\
\hline & Assurance & $\begin{array}{l}\text { Guru membantu siswa dalam memilih } \\
\text { jurusan perguruan tinggi yang sesuai } \\
\text { dengan potensi dan minat }\end{array}$ \\
\hline & & $\begin{array}{l}\text { Peraturan sekolah berlaku untuk semua } \\
\text { siswa }\end{array}$ \\
\hline & & $\begin{array}{l}\text { Terbina komunikasi yang baik antara siswa } \\
\text { dengan guru dan karyawan }\end{array}$ \\
\hline & & $\begin{array}{l}\text { Guru memberikan tugas dengn bijak dan } \\
\text { proporsional kepada siswa }\end{array}$ \\
\hline & & Guru bersikap adil terhadap seluruh siswa \\
\hline & Empaty & $\begin{array}{l}\text { Guru memberikan perhatian kepada siswa } \\
\text { yang belum mengerti materi yang diajarkan }\end{array}$ \\
\hline & & $\begin{array}{l}\text { Guru selalu memberikan motivasi siswa } \\
\text { untuk terus belajar }\end{array}$ \\
\hline & & $\begin{array}{l}\text { Keamanan pada waktu proses belajar } \\
\text { mengajar terjaga }\end{array}$ \\
\hline & & $\begin{array}{l}\text { Proses belajar mengajar yang mudah } \\
\text { dipahami dan dimengerti }\end{array}$ \\
\hline & Responnsiveness & $\begin{array}{llll}\begin{array}{l}\text { Karyawan } \\
\text { administrasi }\end{array} & \text { terampil dalam } & \text { urusan } \\
\end{array}$ \\
\hline & & $\begin{array}{l}\text { Tenaga perpustakaan melayani siswa } \\
\text { dengan baik }\end{array}$ \\
\hline & & Karyawan ramah melayani siswa \\
\hline & & $\begin{array}{l}\begin{array}{l}\text { Karyawan mampu melayani orang tua } \\
\text { dengan baik }\end{array} \\
\end{array}$ \\
\hline & Tangible & Karyawan dan guru berpenampilan rapi \\
\hline & & $\begin{array}{l}\text { Perpustakaan memiliki koleksi buku yang } \\
\text { lengkap }\end{array}$ \\
\hline & & Laboratorium memiliki peralatan lengkap \\
\hline & & $\begin{array}{l}\text { Terdapat sistem informasi sekolah (website) } \\
\text { yang informatif }\end{array}$ \\
\hline & & Lingkungan sekolah yang aman dan bersih \\
\hline & & Meja dan kursi dalam keadaan baik dan rapi \\
\hline & & $\begin{array}{l}\text { Peralatan laboratorium dalam kondisi baik } \\
\text { dan tertata rapi }\end{array}$ \\
\hline & & $\begin{array}{l}\text { Guru membantu siswa dengan segera } \\
\text { terhadap materi yang belum dimengerti }\end{array}$ \\
\hline & & $\begin{array}{l}\text { Karyawan membantu siswa dengan segera } \\
\text { apabila ada kesulitan }\end{array}$ \\
\hline
\end{tabular}




\begin{tabular}{|c|c|c|}
\hline Variabel & Dimensi & Indikator \\
\hline & & $\begin{array}{l}\text { Guru menjawab dengan segera pertanyaan } \\
\text { dari siswa apabila terdapat pertanyaan dan } \\
\text { kesulitan }\end{array}$ \\
\hline
\end{tabular}

Terdapat lima kesenjangan/gap yang mungkin terjadi pada layanan yang diberikan oleh pemberi jasa kepada pelanggan. Pada penelitian kali ini penulis hanya membahas pada gap 5 saja.

Gap $5=$ Persepsi - Harapan (pers.1)

\section{Metode Servqual}

Tjiptono dan Chandra (2016) mengemukakan Model Servqual didasarkan pada asumsi bahwa konsumen membandingkan kinerja jasa pada atribut-atribut relevan dengan standar ideal/sempurna untuk masing-masing atribut jasa. Bila kinerja sesuai dengan atau melebihi standar, maka persepsi atas kualitas jasa keseluruhan akan positif dan sebaliknya. Dengan kata lain, model ini menganalisis gap antara dua variabel pokok, yakni jasa yang diharapkan (expected service) dan jasa yang dipersepsikan (perceived service).

Pengukuran kualitas jasa dalam model Servqual didasarkan pada skala multi-item yang dirancang untuk mengukur harapan dan persepsi pelanggan, serta gap di antara keduanya pada lima dimensi utama kualitas jasa (reliabilitas, daya tanggap, jaminan, empati dan bukti fiksi). Kelima dimensi utama tersebut dijabarkan ke dalam masing-masing 22 atribut rinci untuk variabel harapan dan variabel persepsi, yang disusun dalam pernyataan-pernyataan berdasarkan skala Likert, dari 1 (Sangat Tidak Setuju) sampai 7 (Sangat Setuju) dalam Tabel 2.2. Evaluasi kualitas jasa menggunakan model Servqual mencakup perhitungan perbedaan nilai yang diberikan para pelanggan untuk setiap pasang pernyataan berkaitan dengan harapan dan persepsi. Skor Servqual untuk setiap pasang pernyataan, bagi masing-masing pelanggan dapat dihitung berdasarkan rumus berikut:

\section{Skor Servqual = Skor Persepsi - Skor Harapan}

Pada prinsipnya data yang diperoleh melalui instrumen Servqual dapat dipergunakan untuk menghitung skor gap kualitas jasa pada berbagai level secara rinci: a). Item-by-item analysis, misalnya, $\mathrm{P} 1-\mathrm{H} 1, \mathrm{P} 2-\mathrm{H} 2$ dan seterusnya, b). Dimension-by dimension analisys, contohnya, $(\mathrm{P} 1+\mathrm{P} 2+\mathrm{P} 3+\mathrm{P} 4 / 4)-(\mathrm{H} 1+\mathrm{H} 2+\mathrm{H} 3+\mathrm{H} 4 / 4)$, dimana $\mathrm{P} 1$ sampai $\mathrm{P} 4$ dan $\mathrm{H} 1$ sampai $\mathrm{H} 4$ mencerminkan empat penyataan persepsi dan harapan berkaitan dengan dimensi tertentu, $\mathrm{c}$ ). Perhitungan ukuran tunggal kualitas jasa atau gap Servqual, yaitu $(\mathrm{P} 1+\mathrm{P} 2+\mathrm{P} 3+\ldots+\mathrm{P} 22 / 22)-$ $(\mathrm{H} 1+\mathrm{H} 2+\mathrm{H} 3+\ldots+\mathrm{H} 22 / 22)$

\section{Tabel 2 Dimensi dan Atribut Model Servqual}

\begin{tabular}{lll}
\hline No & Dimensi & Atribut \\
\hline 1 & Reliabilitas & Menyediakan jasa sesuai yang dijanjikan \\
& & Dapat diandalkan dalam menangani masalah jasa pelanggan \\
& Menyampaikan jasa secara benar semenjak pertama kali \\
& & Menyampaikan jasa sesuai dengan waktu yang dijanjikan \\
& & Menyimpan catatan/dokumen tanpa kesalahan \\
2 & Daya Tanggap & Menginformasikan pelanggan kepastian waktu penyampaian jasa \\
& & Layanan yang segera/cepat bagi pelanggan \\
& Ketersediaan untuk membantu pelanggan \\
\hline
\end{tabular}




\begin{tabular}{lll}
\hline No & Dimensi & Atribut \\
\hline \multirow{3}{*}{3} & Jaminan & Kesiapan untuk merespon permintaan pelanggan \\
& & Karyawan yang menumbuhkan rasa percaya para pelanggan \\
& & Membuat pelanggan merasa aman sewaktu melakukan transaksi \\
& & Karyawan yang secara konsiten bersikap sopan \\
& & Karyawan yang mampu menjawab pertanyaan pelanggan \\
& & Memberikan perhatian individual kepada para pelanggan \\
& Empati & Karyawan memperlakukan pelanggan secara penuh perhatian \\
& & Sungguh-sungguh mengutamakan kepentingan pelanggan \\
& & Karyawan yang memahami kebutuhan pelanggan \\
& & Waktu beroperasi (jam kantor) yang nyaman \\
& & Peralatan modem \\
& Bukti Fisik & Fasilitas yang berdaya tarik visual \\
& & Karyawan yang berpenampilan rapi dan profesional \\
& & Materi-materi berkaitan jasa yang berdaya tarik visual \\
&
\end{tabular}

\section{House of Quality}

Cohen (1995) mendefinisikan Quality Function Deployment adalah metode terstruktur yang digunakan dalam prosesperencanaan dan pengembangan produk untuk membangunkebutuhan spesifikasi dan keinginan konsumen, sepertiserta evaluasi yang sistematis dan kemampuan dariproduk atau jasa untuk memenuhi kebutuhan dan keinginan konsumen.

Dalam pengunaan ada beberapa matriks, salah satunya yaitu House of Quality, karena bentuknya menyerupai rumah, antara lain: 1) Voice of Customer (A), merupakan sebuah daftar dari keinginan pelanggan yang didapatkan dari survei secara kualitatif, 2) Planning Matrix (B), merupakan data kuantitatif yang mengindikasikan kepentingan dari Voice of Customer dan tingkat persepsi dan harapan pelanggan, 3) Technical Response (C) atau disebut The Hows, fungsinya untuk menjawab Voice of Customer (The Whats)yang dikembangkan dalam bahasa teknis perusahaan, sehingga menjadi persyaratan yang dapat diukur dan dilaksanakan. ,4) Relationship (D), merupakan penilaian kekuatan korelasi antar tiap elemen dari respon teknis yang ada pada The Hows (C) dengan setiap keinginan dan kebutuhan pelanggan yang ada pada The Whats (A). Dalam pengisian korelasi terdapat simbol yang umum digunakan seperti yang terlihat pada Tabel 1 .

Tabel 1 Value Symbol Relationship pada HoQ

\begin{tabular}{lcc}
\hline Strong & $\bullet$ & 9 \\
\hline Moderate & $\circ$ & 3 \\
\hline Weak & $\nabla$ & 1 \\
\hline
\end{tabular}

Technical Correlation (E) merupakan korelasi teknis yang berisi penilaian hubungan antar respon teknis yang disebut hubungan dan saling ketergantungan antara respon teknis tertentu. Simbol yang digunakan tersaji pada Tabel 2

\begin{tabular}{cl}
\hline $\begin{array}{c}\text { Technical Correlation } \\
\text { pada HoQ Simbol }\end{array}$ & \multicolumn{1}{c}{ Keterangan } \\
\hline+ & Ada hubungan positif antara dua respon teknis \\
\hline- & Ada hubungan negatif antara dua respon teknis \\
\hline$<$ blank $>$ & Tidak ada hubungan antara dua respon teknis \\
\hline
\end{tabular}


Langkah-langkah dalam membuat House of Quality level 1 Matrik HOQ Customer Requirements to Technical Requirement adalah sebagai berikut :

\section{Mengidentifikasi suara pelanggan}

Suara pelanggan (voice of customer) merupakan masukan utama bagi proses pembuatan HOQ. Dari pelanggan diperoleh apa yang sebenarnya pelanggan butuhkan dan inginkan keberadaannya dalam produk/jasa yang ditawarkan. Data-data tersebut diperoleh melalui survey, ataupun dengan menggunakan studi literature maupun dengan diskusi kelompok dengan pihak-pihak yang memahami akan suara pelanggan.

2) Membuat matrik informasi pelanggan.

Matrik informasi pelanggan atau tabel pelanggan adalah bagian horizontal dari matrik HOQ. Tahapan-tahapan penyusunan matrik tersebut sebagai berikut : a) Menentukan daftar atribut keinginan pelanggan (customer requirements), b) Mengidentifikasi tingkat kepentingan (level of importance), c) Mengevaluasi produk/jasa (customer competitive evaluation) yang ditawarkan perusahaan untuk setiap atribut keinginan pelanggan, yang dinyatakan dalam tingkat kepentingan pelanggan (customer rating).

Data-data untuk melakukan kedua tahapan pertama diperoleh dari hasil survey yang dilakukan pada langkah sebelumnya, sedangkan untuk langkah yang ketiga digunakan data hasil pengolahan yang terdapat pada tabel tingkat kepentingan dan tabel evaluasi kompetitif.

\section{Membuat matrik kebutuhan teknikal}

Dalam menyelesaikan tabel informasi teknikal (technical table) ini, tim perancang dapat mengikuti langkah-langkah sebagai berikut : a). Identifikasi respon teknikal yang diperlukan untuk memenuhi keinginan pelanggan. Respon teknikal merupakan karakteristik desain yang menjelaskan kebutuhan dan keinginan pelanggan yang diekspresikan dalam bahasa desainer dan teknik. Pada intinya respon teknikal adalah "HOWs" dengan mana perusahaan akan menanggapi "WHATs" - atribut keinginan pelanggan, b). Menentukan hubungan (relationship) antara respon teknikal (technical response) dengan keinginan pelanggan (customer requirement). Hubungan ini ditentukan oleh tim QFD sendiri karena aspek-aspek yang dinilai tidak dapat dimengerti oleh orang awam. Jenis hubungan yang terdapat dalam matrik ini adalah : 1) Hubungan kuat ( $\bullet$ ), Hubungan yang terjadi apabila respon teknikal sebagai hal hal yang dilakukan perusahaan, berhubungan sangat erat atau sangat mempengaruhi keinginan pelanggan, bobotnya 9. 2). Hubungan sedang ( o ), Hubungan yang terjadi apabila respon teknikal berhubungan erat atau mempengaruhi terpenuhnya keinginan pelanggan, bobotnya 3, 3) Hubungan lemah ( o ), Hubungan yang terjadi apabila respon teknikal tidak begitu mempengaruhi terpenuhnya keinginan pelanggan bobotnya 1 .

\section{Menghitung nilai bobot respon teknikal}

Penilaian respon teknikal dihitung berdasarkan tingkat keterhubungan antar respon teknikal terhadap keinginan pelanggan dan tingkat kepentingan. Bobot respon teknikal merupakan suatu ukuran yang menunjukkan respon teknikal yang perlu mendapatkan perhatian atau diprioritaskan dalam hubungannya dengan pemenuhan keinginan pelanggan. Prioritas tersebut tergantung dari kepentingan absolute (Absolute Importance - AI) dan kepentingan relative (Relative Importance - RI). Kepentingan absolute merupakan suatu indikasi yang menunjukkan keinginan pelanggan yang paling utama, yang harus segera dipenuhi oleh perusahaan dalam hubungannya dengan teknikal. Sedangkan kepentingan relatif merupakan angka dalam persen kumulatif.

\section{Penentuan arah pengembangan}

Arah pengembangan (Direction of Improvement - DOI) merupakan arah perubahan yang harus dilakukan perusahaan terhadap respon teknikal untuk dapat meningkatkan kepuasan pelanggan. Simbol-simbol yang digunakan pada ruang arah pengembangan adalah sebagai berikut : a). ( $\uparrow)$ simbol ini dipergunakan pada respon teknikal yang akan meningkatkan kepuasan pelanggan apabila lebih besar, lebih tinggi, lebih berat atau singkatnya "more", b). ( $\downarrow$ ) simbol ini dipergunakan pada respon teknikal yang akan menigkatkan kepuasan pelanggan apabila lebih kecil, lebih pendek, lebih ringan, atau singkatnya "less", c). (o) simbol ini 
dipergunakan pada respon teknikal yang akan memberikan kepuasan pada pelanggan apabila terdapat pada target (jangkauan nilai ) tertentu.

\section{Penentuan korelasi teknikal}

Korelasi teknikal (technical correlation) merupakan hubungan saling keterkaitan antar masing-masing respon teknikal. Hubungan pada korelasi teknikal tersebut adalah: a). Hubungan positif kuat merupakan hubungan di mana bila salah satu item respon teknikal mengalami peningkatan atau penurunan, maka akan berdampak kuat pada peningkatan atau penurunan item yang terkait. Hubungan ini merupakan hubungan yang searah, yaitu apabila salah satu item mengalami peningkatan maka item lain yang terkait akan mengalami peningkatan juga, b). Hubungan positif merupakan hubungan searah di mana bila salah satu item respon teknikal mengalami peningkatan atau penurunan, maka akan menyebabkan peningkatan atau penurunan pada item lain yang terkait, c). Hubungan negative merupakan hubungan berlawanan arah, yaitu bila salah satu item respon teknikal mengalami peningktan maka akan menyebabkan penurunan pada item lain yang terkait, d) Hubungan negatif kuat merupakan hubungan berlawanan arah yang kuat, yaitu dampak akibat peningkatan salah satu item pada respon teknikal sangat kuat pada penurunan item lain yang terkait. Tidak seluruh item dari respon teknikal akan memiliki keterkaitan atau memiliki pengaruh terhadap item respon teknikal lainnya, sehingga ada kemungkinan kolom yang kosong.

\section{Menentukan target}

Dari respon teknikal serta evaluasinya, perusahaan selanjutnya menentukan target yang ingin dicapai, yaitu penentuan respon teknikal yang dapat memenuhi keinginan pelanggan. Target ini ditentukan berdasarkan pada skala nilai yang sama dengan evaluasi respon teknikal atau dapat pula berupa keterangan tindakan yang akan diambil.

\section{HASIL DAN PEMBAHASAN}

Penelitian ini bertujuan untuk menentukan faktor-faktor yang mempengaruhi kepuasan siswa terhadap layanan pendidikan serta untuk menganalisis atribut-atribut kualitas layanan pendidikan di SMA YASPORBI yang pada akhirnya dapat digunakan sebagai pertimbangan Yayasan Yasporbi sebagai pemilik sekolah dalam meningkatkan kualitas layanan. Adapun temuan utama dalam penelitian ini adalah:

\section{Faktor-Faktor yang Mempengaruhi Kepuasan Siswa}

Berdasarkan hasil interview dan observasi yang dilakukan, maka dapat diidentifikasi 32 atribut layanan pendidikan yang menjadi customer requirements dari SMA YASPORBI. Identifikasi tersebut berdasarkankepada 5 komponen service quality, yaitu : bukti langsung (tangibles), kehandalan(reliability), daya tangkap (responsiveness), jaminan (assurance) dan empati(emphaty), berikut ini adalah uraian dari masng-masing atribut pelayanan tersebut:

\section{1) Kehandalan (reliability),}

a) Prosedur penerimaan siswa yang mudah dan cepat,

Prosedur penerimaan siswa yang mudah dan cepat sangat dibutuhkansiswa baru agar mereka lebih cepat mengetahui diterima atau tidaknyasiswa baru. Hal ini agar siswa dapat mencari sekolah yang lain jika tidak diterima.

b) Proses belajar mengajar dijalankan dengan baik dan lancar Proses belajar mengajar harus dijalankan dengan baik dan lancar agar siswa menjadi lebih optimal dalam belajar.

c) Jadwal pelajaran dijalankan dengan tepat

Proses belajar mengajar harus dijalankan dengan tepat waktu agarpelayanan kegiatan belajar mengajar berlangsung tepat waktu.

d) Isi pembelajaran berguna untuk mempersiapkan siswa dalam SPMB 
Isi pembelajaran yang diajarkan tentunya harus berguna untuk siswadalam menghadapi seleksi penerimaan mahasiswa baru.

e) Guru mampu menyampaikan materi dengan baik Agar kegiatan belajar mengajar berlangsung dengan baik maka guruseharusnya mampu menyampaikan materi pelajaran dengan baik dan menarik sehingga siswa menjadi tertarik untuk belajar.

f) Guru bidang studi mengajar sesuai dengan latar belakang pendidikannya

Guru bidang studi sebaiknya mengajar sesuai dengan latarbelakangpendidikannya agar guru mudah dalam mengajar dan menyampaikanmateri sekolah.

\section{Jaminan (assurance)}

a) Ada pelatihan dalam mempersiapkan siswa menghadapi SPMB

Dalam menyiapkan siswa menghadapi seleksi penerimaan mahasiswa barudibutuhkan pelatihan agar siswa siap dalam menghadapi seleksi.

b) Guru membantu siswa dalam memilih jurusan perguruan tinggi sesuai dengan potensi dan minat siswa

Guru harus memberikan perhatian dan membantu siswanya dalammemberikan dan mengarahkan pilihan jurusan kepada siswa sesuai denganbakat dan minat siswa dalam memilih perguruan tinggi.

c) Peraturan sekolah berlaku untuk semua siswa

Peraturan dan tata tertib sekolah harus berlaku untuk semua siswa agarsiswa merasa adil dan tidak dibeda-bedakan antara siswa yang satu denganyang lain.

d) Terbina komunikasi yang baik antara siswa dengan guru dan karyawan

Komunikasi yang baik sangat dibutuhkan dalam memperlancar kegiatanbelajar mengajar di sekolah.

e) Guru memberikan tugas dengan bijak dan proporsional kepada siswa

Guru harus memberikan tugas dengan bijak dan proporsional karena tugastidak boleh membebani siswa dikarena waktu yang dimiliki tidaklah cukupdengan melihat jam sekolah dari pagi hingga malam hari.

f) Guru bersikap adil terhadap seluruh siswa

Dalam menyampaikan dan interaksi dalam kelas guru harus bersikap adilterhadap siswa sehingga siswa menjadi aktif dan semangat dalam belajar.Murid menjadi merasa adil dalam pelayanan mengajar.

\section{Empati (Emphaty)}

a) Guru memberikan perhatian kepada siswa yang belum mengerti

Perhatian dari seorang guru sangatlah penting terhadap siswa yang belummengerti karena tidak semua siswa langsung dapat mengerti dalammenerima pelajaran sehingga dibutuhkan perhatian khusus.

b) Guru mudah ditemui apabila ada siswa yang ingin berkonsultasi tentang pelajaran yang belum mengerti

Kemudahaan dalam menemui guru sangat dibutuhkan jika ada siswa yangingin berkonsultasi terhadap pelajaran yang belum dimengerti.

c) Guru memiliki kreatifitas dalam mengajar

Guru merupakan salah satu komponen penting dalam keberhasilan dalamkegiatan belajar mengajar. Oleh karena itu dibutuhkan guru yang memilikikreatifitas dalam mengajar agar suasana belajar lebih menjadi kondusifsehingga siswa merasa senang dan nyaman dalam belajar di kelas.

d) Guru selalu memberikan motivasi siswa untuk terus belajar

Guru sangat dibutuhkan untuk memotivasi siswa agar apa yang ia cita-citakanmenjadi terwujud. Oleh karena itu seorang guru harus mampumelihat dan membaca bakat dan minat siswa sehingga dapat terusmemotivasinya.

e) Keamanan pada waktu proses belajar mengajar terjaga

Agar kegiatan belajar dan mengajar dapat berjalan dengan baik dan lancardibutuhkan rasa aman dan nyaman terhindar dari bahaya supaya kegiatanbelajar mengajar menjadi lancar 
f) Proses belajar mengajar yang mudah dipahami dan dimengerti

Proses belajar mengajar yang mudah dipahami dan dimengerti sangat dibutuhkan agar siswa dapat dengan mudah mempelajari pelajaran yang diajarkan oleh sekolah.

g) Karyawan terampil dalam urusan administrasi

Urusan administrasi sangat mendukung dalam mendaptkan informasi dandata-data siswa sehingga harus ditangani oleh karyawan yang mengertiurusan administrasi sehingga dapat cepat dan mudah jika dibutuhkan.

h) Tenaga perpustakaan melayani siswa dengan baik

Tenaga perpustakaan harus mampu melayani siswa dengan baik jika adasiswa yang ingin meminjam dan membaca buku. Tenaga perpustakaanjuga harus melayani siswa dengan baik agar siswa menjadi senang untukke perpustakaan.

i) Karyawan ramah dalam melayani siswa

Selain terampil dalam urusannya, karyawan juga harus bersikap ramahkepada siswa dalam pelayanannya sehingga siswa merasa nyamanberkomunikasi dengan karyawan.

j) Karyawan mampu melayani orang tua siswa dengan baik

Karyawan selain mampu melayani siswa dengan baik juga harus mampumelayani orang tua siswa dengan baik pula agar terjadi komunikasi yangbaik.

\section{Bukti Langsung (Tangible)}

a) Karyawan dan guru berpenampilan rapi

Penampilan karyawan dan guru harus rapi dan bersih agar dapat menjadicontoh siswa.

Karena guru merupakan panutan bagi siswa.

b) Perpustakaan memiliki koleksi buku yang lengkap

Perpustakaan dengan kolekasi buku yang lengkap diharapkan dapatmembantu siswa dalam menambah wawasan dan menyelesaikan tugas-tugasmereka.

c) Laboratorium memiliki peralatan yang lengkap

Laboratorium dengan peralatan yang lengkap diharapkan siswa yangpraktikum dapat berjalan dengan baik dan lancar.

d) Terdapat sistem informasi sekolah (website) yang informatif

Sistem informasi sekolah dengan memanfaatkan fasilitas internet sangatberguna untuk membantu siswa atau orang lain dalam mendapatkaninformasi sekolah.

e) Lingkungan sekolah yang aman dan bersih

Lingkungan sekolah yang aman dan bersih diharapkan dapat membuatsiswa menjadi nyaman sehingga proses belajar mengajar menjadi lancar.

f) Meja dan kursi dalam keadaan baik dan rapi

Meja dan kursi dalam keadaan baik dan rapi dimaksudkan agar siswadapat belajar dengan baik.

g) Peralatan lab dalam kondisi baik dan tertata rapi

Peralatan lab dalam kondisi baik dan tertata rapi agar siswa yang praktikum berjalan lancar dan memudahkan siswa dalam mempersiapkan alat-alat praktikum sebelum praktikum dimulai Daya Tangkap (responsiveness)

h) Guru membantu siswa dengan segera terhadap materi pelajaran yang belum dimengerti Kecepatan dan kesegeraan guru dalam membantu siswa yang belummengerti terhadap pelajaran sangat dibutuhkan agar siswa menjaditerbantu dan merasa diperhatikan sehingga materi pelajaran dapat segerasiswa mengerti.

i) Karyawan membantu siswa dengan segera apabila ada kesulitan

Karyawan harus mampu melayani siswa dengan cepat dan segera jika adakesulitan yang didapatkan siswa.

j) Guru menjawab dengan segera pertanyaan dari siswa apabila terdapat pertanyaan dan kesulitan

Sebaiknya guru mampu menjawab pertanyaan dari siswa dengan segeraagar siswa lebih cepat mendapatkan jawaban dari pertanyaan dankesulitannya itu. 
Kuisioner dibuat berdasarkan pada kebutuhan pelanggan, yang diklasifikasikan ke dalam lima dimensi Service Quality yaitu Tangible, Reliability, Responsiveness, Assurance, dan Emphaty seperti yang disajikan pada Tabel 3 .

Tabel 3. Klasifikasi Pertanyaan Menurut Dimensi Service Quality

\begin{tabular}{|c|c|c|}
\hline Variabel & Dimensi & Indikator \\
\hline \multirow[t]{2}{*}{ Pendidikan } & Reliability & $\begin{array}{l}\text { Prosedur layanan penerimaan siswa mudah dan cepat } \\
\text { Proses belajar mengajar dijalankan dengan baik dan } \\
\text { lancar } \\
\text { Jadwal pelajaran dijalankan dengan tepat dan disiplin } \\
\text { Isi pembelajaran berguna untuk menyiapkan siswa } \\
\text { dalam seleksi penerimaan mahasiswa baru } \\
\text { Guru mampu menyampaikan materi pelajaran dengan } \\
\text { baik } \\
\text { Guru mata pelajaran mengajar sesuai dengan latar } \\
\text { belakang pendidikannya } \\
\text { Ada pelatihan dalam mempersiapkan siswa menghadapi } \\
\text { seleksi penerimaan mahasiswa baru }\end{array}$ \\
\hline & Assurance & $\begin{array}{l}\text { Guru membantu siswa dalam memilih jurusan } \\
\text { perguruan tinggi yang sesuai dengan potensi dan minat }\end{array}$ \\
\hline \multirow[t]{4}{*}{ Variabel } & Dimensi & Indikator \\
\hline & Empaty & $\begin{array}{l}\text { Peraturan sekolah berlaku untuk semua siswa } \\
\text { Terbina komunikasi yang baik antara siswa dengan guru } \\
\text { dan karyawan } \\
\text { Guru memberikan tugas dengn bijak dan proporsional } \\
\text { kepada siswa } \\
\text { Guru bersikap adil terhadap seluruh siswa } \\
\text { Guru memberikan perhatian kepada siswa yang belum } \\
\text { mengerti materi yang diajarkan } \\
\text { Guru selalu memberikan motivasi siswa untuk terus } \\
\text { belajar } \\
\text { Keamanan pada waktu proses belajar mengajar terjaga } \\
\text { Proses belajar mengajar yang mudah dipahami dan } \\
\text { dimengerti }\end{array}$ \\
\hline & Responnsiveness & $\begin{array}{l}\text { Karyawan terampil dalam urusan administrasi } \\
\text { Tenaga perpustakaan melayani siswa dengan baik } \\
\text { Karyawan ramah melayani siswa } \\
\text { Karyawan mampu melayani orang tua dengan baik }\end{array}$ \\
\hline & Tangible & $\begin{array}{l}\text { Karyawan dan guru berpenampilan rapi } \\
\text { Perpustakaan memiliki koleksi buku yang lengkap } \\
\text { Laboratorium memiliki peralatan lengkap } \\
\text { Terdapat sistem informasi sekolah (website) yang } \\
\text { informatif } \\
\text { Lingkungan sekolah yang aman dan bersih }\end{array}$ \\
\hline
\end{tabular}




\begin{tabular}{ll}
\hline Variabel $\quad$ Dimensi & Indikator \\
\hline & Meja dan kursi dalam keadaan baik dan rapi \\
& Peralatan laboratorium dalam kondisi baik dan tertata \\
& rapi \\
& Guru membantu siswa dengan segera terhadap materi \\
& yang belum dimengerti \\
& Karyawan membantu siswa dengan segera apabila ada \\
& kesulitan \\
& Guru menjawab dengan segera pertanyaan dari siswa \\
& apabila terdapat pertanyaan dan kesulitan \\
\hline
\end{tabular}

Setelah dilakukan penyebaran kuisioner kepada 72 responden, kemudian dihitung nilai Gap 5. Berikut adalah Tabel yang menunjukkan selisih (Gap 5) antara tingkat persepsi dan tingkat harapan:

\begin{tabular}{llll}
\hline \multirow{2}{*}{ NO } & Nilai & Nilai & Gap \\
& Persepsi & Ekspektasi & Score \\
\hline 1 & 4.11 & 4.08 & 0.03 \\
2 & 4.25 & 4.03 & 0.23 \\
3 & 4.11 & 4.01 & 0.09 \\
4 & 4.25 & 4.09 & 0.16 \\
5 & 3.79 & 4.01 & -0.23 \\
6 & 4.25 & 3.91 & 0.35 \\
7 & 4.25 & 4.08 & 0.17 \\
8 & 4.25 & 4.15 & 0.11 \\
9 & 3.79 & 4.25 & -0.47 \\
10 & 4.21 & 4.27 & -0.05 \\
11 & 4.11 & 3.97 & 0.13 \\
12 & 3.79 & 4.21 & -0.43 \\
13 & 4.11 & 4.25 & -0.15 \\
14 & 3.79 & 3.97 & -0.19 \\
15 & 4.51 & 4.20 & 0.31 \\
16 & 3.79 & 4.20 & -0.41 \\
17 & 4.55 & 4.15 & 0.40 \\
18 & 3.95 & 4.24 & -0.29 \\
19 & 4.51 & 4.21 & 0.29 \\
20 & 4.11 & 4.03 & 0.08 \\
21 & 4.11 & 4.03 & 0.08 \\
22 & 4.16 & 4.25 & -0.09 \\
23 & 4.51 & 4.07 & 0.44 \\
24 & 4.16 & 4.11 & 0.05 \\
25 & 4.25 & 4.09 & 0.16 \\
26 & 4.21 & 4.09 & 0.12 \\
27 & 4.25 & 4.09 & 0.16 \\
28 & 4.56 & 4.37 & 0.19 \\
29 & 4.51 & 4.32 & 0.19 \\
30 & 4.21 & 4.32 & -0.11 \\
31 & 4.56 & 4.31 & 0.25 \\
32 & 4.21 & 4.67 & -0.45 \\
\hline & & &
\end{tabular}




\section{House of Qulity (HOQ) Level 1}

Dalam menyusun House of Quality (HOQ) Level 1, kita akan menggunakan data-data yang berkaitan dengan customer requirements yang merupakan atribut pelayanan pendidikan serta respon teknikal dari pihak manajemen SMA YASPORBI dan YAYASAN YASPORBI. Diperlukan penyesuaian tingkat kepentingan (Adjusted Importance) atribut pelayanan sebelum kemudian akan diintegrasikan kedalam House of Quality, sehingga diperlukan perhitungan nilai adjusted importance dari atribut pelayanan-pelayanan tersebut.

\section{Analisis HOQ Level 1}

Dari hasil penyusunan $\mathrm{HOQ}$, diperoleh prioritas langkah-langkah dalam upaya peningkatan kualitas jasa, dengan menggunakan metode Servqualyang kemudian diintegrasikan ke dalam House of Quality, tingkat kepentingan dari masing-masing atribut yang bernilai negatif merupakan customer requirement, dimana denganmetode ini tentunya semakin mempertajam prioritas perhatian pada atribut-atribut yang mempunyai pengaruh besar dalam memberikan kontribusi kepuasan pelanggan.

\section{Target dan Arah Perbaikan Respon Teknikal}

Arah perbaikan dikategorikan dalam tiga kelompok yaitu: 1) Naik, artinya semakin tinggi nilai yang dicapai maka akan semakin baik, 2). Tetap, artinya target yang dituju sudah baik, 3) Turun, artinya semakin rendah nilai tersebut, maka akan semakin baik. Jadi arah perbaikan respon teknikal adalah arah mana yang sebaiknya dituju setiap respon teknikal terhadap nilai targetnya. Dalam penelitian ini kita dapat melihat terdapat sebanyak 4 respon teknikal yang mempunyai arah perbaikan tetap dan 10 lainnya mempunyai arah teknikal yang naik.

Berkaitan dengan kualitas jasa harus dimulai dari kebutuhan pelanggan dan berakhir dengan kepuasan pelanggan serta persepsi positif terhadap kualitas jasa. Sebagai pihak yang membeli dan mengkonsumsi jasa, pelanggan (dan bukan penyedia jasa) yang menilai tingkat kualitas jasa sebuah perusahaan (Kotler \& Keller, 2016).

Untuk itu ada beberapa penelitian yang mendukung penelitian ini antara lain: Penelitian oleh Hanggara et. al Tahun 2010, tujuan penelitian ini adalah mengintegrasikan metode Service Quality (Servqual) dengan Quality Function Deployment (QFD) yang menghasilkan proses penyempurnaan berkelanjutan (continual improvement) terhadap kinerja sekolah sehingga kualitas dan output sekolah sebagai sebuah institusi pendidikan selalu menjadi lebih baik dari waktu ke waktu. Karena itu perlu adanya peninjauan terhadap konsumen untuk meningkatkan kualitas dari lembaga pendidikan terkait sehingga layanan lembaga pendidikan di SMKN 6 Kota Malang semakin baik. Penelitian ini menggunakan integrasi metode Service Quality (Servqual) dan Quality Function Deployment (QFD). Fungsi dari integrasi tersebut adalah memperjelas perencanaan untuk melakukan perbaikan. Integrasi ini di lakukan dengan memanfaatkan gap persepsi dan ekspektasi pada room I House of Quality, dan hasil dari pengukuran Servqual digunakan pada room II House of Quality.

Penelitian yang dilakukan oleh Amini \& Akhlaqi Tahun 2012, penelitian ini mencoba untuk menilai perspektif kualitas pendidikan, melalui Servqual. Metodologi Servqual terbukti menjadi alat yang ampuh untuk menganalisis kualitas layanan di bagian yang berbeda dari ilmu pengetahuan dan industri. Hasil penelitian menunjukkan bahwa di pusat pendidikan saat ini, ada kesenjangan kualitas dalam semua kualitas pelayanan ukuran, kesenjangan yang paling menonjol adalah untuk dimensi responsiveness dan keandalan.

Adapun perbandingan dari penelitian saat ini dengan hasil review penelitian sebelumnya secara umum dapat dilihat pada Tabel 4 dimana dapat dilihat kriteria yang digunakan, metode analisanya, serta kelebihan dan kekurangan dari setiap penelitian. 
Tabel 4 Hasil Review Penelitian sebelumnya dan saat ini

\begin{tabular}{|c|c|c|c|}
\hline Peneliti & Penelitian Ini (2016) & Hanggara et. al (2010) & $\begin{array}{l}\text { Amini } \\
(2012)\end{array} \quad \& \quad$ Akhlaqi \\
\hline Tujuan/Tema & $\begin{array}{l}\text { Analisis } \quad \text { Kualitas } \\
\text { Layanan Pendidikan }\end{array}$ & $\begin{array}{l}\text { Analisis Kualitas Layanan } \\
\text { Pendidikan }\end{array}$ & $\begin{array}{l}\text { Analisis Kualitas } \\
\text { Layanan Pendidikan }\end{array}$ \\
\hline Metode & $\begin{array}{l}\text { Servqual dan Quality } \\
\text { Function } \\
\text { Deployment }\end{array}$ & $\begin{array}{l}\text { Quality Function } \\
\text { Deployment, Service Quality, } \\
\text { dan peningkatan kualitas. }\end{array}$ & $\begin{array}{l}\text { Fuzzy } \\
\text { Quality } \\
\text { Function Deployment } \\
\text { (QFD) }\end{array}$ \\
\hline Hasil & $\begin{array}{l}\text { Servqual } 11 \text { layanan } \\
\text { perlu perbaikan dan } \\
4 \text { teknikal respon } \\
\text { pada House of } \\
\text { Quality Level } 2\end{array}$ & $\begin{array}{l}\text { memperjelas perencanaan } \\
\text { untuk melakukan perbaikan. } \\
\text { Integrasi ini di lakukan } \\
\text { dengan memanfaatkan gap } \\
\text { persepsi dan ekspektasi pada } \\
\text { room I House of Quality, dan } \\
\text { hasil dari pengukuran } \\
\text { Servqual digunakan pada } \\
\text { room II House of Quality }\end{array}$ & $\begin{array}{l}\text { rancangan strategi } \\
\text { perbaikan layanan } \\
\text { yaitu maintenance } \\
\text { komputer, perbaikan } \\
\text { komputer yang rusak, } \\
\text { pemberian pendidikan } \\
\text { dan pelatihan bagi } \\
\text { dosen dan karyawan }\end{array}$ \\
\hline Kelebihan & $\begin{array}{l}\text { Menterjemahkan } \\
\text { proses pengerjaan } \\
\text { secara jelas dan } \\
\text { komprehensif }\end{array}$ & $\begin{array}{lr}\text { Proses } & \text { penyempurnaan } \\
\text { berkelanjutan } & \text { (continual } \\
\text { improvement) } & \text { terhadap } \\
\text { kinerja sekolah } & \\
\end{array}$ & $\begin{array}{l}\text { Menggunakan Kano } \\
\text { Model pada proses } \\
\text { integrasi metode }\end{array}$ \\
\hline Kekurangan & $\begin{array}{l}\text { Tidak menggunakan } \\
\text { matrik IPA }\end{array}$ & - & - \\
\hline
\end{tabular}

Sumber : Pengolahan Data, 2016

\section{Implikasi Industri}

Upaya dari pengelola institusi pendidikan untuk meningkatkan mutu pendidikan berdasarkan manajemen perusahaan. Penerapan manajemen mutu pendidikan ini lebih populer dengan istilah Total Quality Education (TQE). Dasar dari manajemen ini dikembangkan dari konsep Total Quality Manajemen (TQM), yang mulanya diterapkan pada dunia bisnis kemudian diterapkan pada dunia pendidikan. Secara filosofis, konsep ini menekankan pada pencarian secara konsisten terhadap perbaikan yang berkelanjutan untuk mencapai kebutuhan dan kepuasan pelanggan.

Model Servqual (singkatan dari service quality) adalah merupakan model kualitas jasa yang paling populer dan dijadikan acuan dalam riset manajemen dan pemasaran jasa yang dikenal dengan istilah Gap Analisys Model yang berkaitan erat dengan model kepuasan pelanggan. Model ini menegaskan bila kinerja pada suatu atribut (attribute Performance) meningkat lebih besar daripada harapan (expectations) atas atribut bersangkutan, maka persepsi terhadap kualitas jasa akan menjadi positif dan sebaliknya.

Quality Function Deployment (QFD) berkaitan dengan (1) menetapkan apa yang akan memuaskan pelanggan dan (2) menerjemahkan keinginan pelanggan pada desain yang dijadikan sasaran. Idenya adalah untuk memahami keinginan pelanggan dan memperkenalkan solusi proses alternatif kepada mereka. Kemudian, informasi ini dipadukan diawal proses desain untuk membantu menetapkan apa yang dapat memuaskan pelanggan dan dimana upaya-upaya kualitas perlu disebarkan. Suatu perangkat QFD adalah rumah kualitas (House of Quality), rumah kualitas merupakan teknik grafis untuk menjelaskan hubungan antara keinginan pelanggan dan produk (atau jasa). 


\section{SIMPULAN}

Berdasarkan tujuan yang ingin dicapai dalam penelitian ini dapat diperoleh beberapa kesimpulan sebagai berikut:

1. Faktor-faktor yang mempengaruhi kepuasan siswa terhadap pelayanan pendidikan di SMA YASPORBI setelah dilakukan observasi dan diskusi dengan pihak sekolah berkaitan dengan 5dimensi kualitas pelayanan, yaitu tangibles (bukti langsung), reliability(kehandalan), responsiveness (daya tanggap), assurance (jaminan) dan emphaty(empati) diperoleh 32 butir atribut yang dapat mempengaruhi kepuasan siswa terhadap pelayanan pendidikan.

2. Atribut-Atribut pelayanan pendidikan yang mempunyai nilai gap score negatif dan ada 21 atribut pelayanan pendidikan yang mempunyai nilai positif. Untuk ke 11 atribut pelayanan pendidikan yang mempunyai nilai gap score negatif perlu mendapatkan perhatian dan perbaikan, sehingga dibutuhkan langkah-langkah perbaikan yang dijabarkan dalam analisa QFD. Atribut pelayanan pendidikan yang perlu dilakukan perbaikan, diantaranya adalah:

a. Guru mampu menyampaikan materi pelajaran dengan baik

b. Peraturan sekolah berlaku untuk semua siswa

c. Terbina komunikasi yang baik antara siswa dengan guru dan karyawan

d. Guru bersikap adil terhadap seluruh siswa

e. Guru memberikan perhatian kepada siswa yang belum mengerti materi yang diajarkan

f. Guru mudah ditemui apabila ada siswa yang ingin berkonsultasi tentang pelajaran yang belum dimengerti

g. Guru selalu memberikan motivasi siswa untuk terus belajar

h. Proses belajar mengajar yang mudah dipahami dan dimengerti

i. Karyawan mampu melayani orang tua dengan baik

j. Guru membantu siswa dengan segera terhadap materi yang belum dimengerti

k. Guru menjawab dengan segera pertanyaan dari siswa apabila terdapat pertanyaan dan kesulitan

\section{SARAN}

Berdasarkan hasil-hasil yang diperoleh maka disampaikan saran yang dapat membantu perusahaan dalam rangka meningkatkan produktivitas perusahaan di masa yang akan datang, adapun saran - saran yang dapat diberikan adalah sebagai berikut :

1. Mengadakan pelatihan, workshop, dan seminar pendidikan pelatihan secara berkala agar karyawan bisa melakukan kaizen (continous improvement).

2. Melakukan Evaluasi terhadap Pencapaian kinerja, Perbaikan dan System yang ada secara berkala agar perbaikan mendapatkan hasil yang maksimal.

3. Melakukan Penelitian Lanjutan mengenai hal-hal yang perlu diperbaiki dalam pengembangan program, murid dan kurikulum yang melibatkan seluruh aspek di lingkungan sekolah agar diperolah rencana perbaikan dan hasil yang maksimal.

4. Menerapkan Budaya yang sehat dilingkungan sekolah yang diharapkan akan mempengaruhi pla hidup dan pergaulan yang sehat untuk seluruh karyawan dan siswa yang ada di lingkungan sekolah.

\section{DAFTAR RUJUKAN}

Akhlaghi, E., Amini, S., \& Akhlaghi, H. (2012). Evaluating educational service quality in technical and vocational colleges using SERVQUAL model.Procedia-Social and Behavioral Sciences, 46(4), 5285-5289. 
Hanggara, F. D., Sugiono, S., \& Efranto, R. Y. (2014). Analisis Kualitas Layana berbasis Servqual Terintegrasi dengan Metoda QFD. Jurnal Rekayasa dan Manajemen Sistem Industri, 2(4), 809-819.

Heizer, J., \& Render, B. (2009) Operation Management(Manajemen Operasi) Education, Inc Salemba Empat, Jakarta.

Kotler, P., \& Keller, K. L. (2016). Manajemen Pemasaran. Pearson Education, Inc - PT. Indeks, Jakarta

Sallis, E. (2012). Total Quality Management in Education. IRCiSod - Yogyakarta

Tjiptono, F., \& Chandra, G. (2016) Service, Quality danSatisfaction : Edisi 4. Andi, Yogyakarta

Wulandari, S. H. E., \& Ciptomulyono, U. (2011). Strategi Peningkatan Kualitas Layanan Pendidikan menggunakan integrasi Metode fuzzy servqual dan QFD. Jurnal Magister Manajemen Teknik Industri ITS: Surabaya. 2(3), 20-32. 